\title{
Isaac Newton and the Medals for Queen Anne
}

\author{
Joseph Hone
}

\begin{abstract}
A BSTRACT During the reign of Queen Anne, medals became an established vessel for government propaganda. Medal designs were tightly regulated by ministry officials. As master of the Mint, Isaac Newton was responsible for Anne's medallic policy. A vast array of materials, ranging from polemical pamphlets to satirical verse, testify to the political impact of Newton's medals. Contrary to portrayals of Newton as an aloof scholar whose job at the Mint was a sinecure, this essay argues that Newton was alive to contemporary political debates and designed medals himself at the behest of senior ministers. KEYWORDS: material culture of Anne's queenship; John Croker; political propaganda in early eighteenth-century England; responses to Sun King imagery; medals as loyalist symbols
\end{abstract}

W WEN QUEEN ANNE ACCEDED to the throne on March 8, 1702, there was little to no tradition of state-sponsored medal-making. Except in the case of coronation medals, Mint officials were free to design and produce commemorative medals as they saw fit, with minimal oversight. By the time of Anne's death in 1714, though, medals had become a regulated mode of ministry propaganda, subject to the same pressures and interventions as government-funded pamphlets, poems, and newspapers. How and why did this change come about? As master of the Mint, Isaac Newton was instrumental in enacting this overhaul. His willingness to embrace intervention from ministers and the queen herself-as well as his personal input into design-facilitated the transformation of the Mint into a factory for government propaganda.

The scholarly neglect of Anne's medallic image is surprising, as she came to the throne in what was a golden age for the production of medals in Europe. As Peter Burke and Sir Mark Jones have shown, medals were central to Louis XIV's propaganda, helping disseminate his Sun King image both at home and abroad. ${ }^{1}$ In 1663 he set up an

1. Peter Burke, The Fabrication of Louis XIV (New Haven, Conn., 1994); Sir Mark Jones, Medals of the Sun King (London, 1979); Robert Wellington, Antiquarianism and the Visual Histories of Louis XIV:

Pp. 119-48. () 2016 by Henry E. Huntington Library and Art Gallery. IssN 0018-7895 | E-ISSN 1544-399x. All rights reserved. For permission to photocopy or reproduce article content, consult the University of Pennsylvania Press Rights and Permissions website, http://www.upenn.edu/pennpress/about/permissions.html. 
official body_l'Académie royale des inscriptions et médailles-responsible for regulating this outlet for his image, and he had several histoires métallique printed by royal command. Perhaps influenced by its surroundings at Saint-Germain-en-Laye, the Jacobite court also produced medals designed to legitimate the claim of James Francis Edward Stuart-known variously as the "Pretender" and "James III" - to the throne. Recent scholarship by Neil Guthrie and Murray Pittock has demonstrated the significance of those medals in the British Isles and overseas. ${ }^{2}$ Lacking the romance of these Jacobite objects or the opulence of examples from the French court, English medals of the period have been neglected. Even James Anderson Winn and Kevin Sharpe, in their excellent recent work on Anne's public image, have assigned only a minor role to medals and their political impact. ${ }^{3}$ Nonetheless, at the time, official English medals were both more widespread and more commented upon than illicit medals smuggled from across the Channel. By concentrating on particular aspects of Anne's queenship, notably her commitment to war with France, Newton and his colleagues entered into dialogue with medallic practitioners on the Continent. But medals could also be political dynamite, and they were frequently appropriated by publicists and made to carry a particular partisan coloring. Hence, in exploring how Anne was represented to her subjects and how they, in turn, responded to her image, we need to bear in mind the resonance of medallic propaganda.

\section{$\sim$ Medallic Culture in the Age of Queen Anne}

Ownership of medals in the early eighteenth century was, by and large, limited either to those with the disposable income to purchase such items from a retailer or to persons who distinguished themselves in the service of the Crown. Medals did not come cheap. Official copper medals could be had for a shilling and sixpence, but toward the end of Anne's reign these grew in size and weight, and thus price, retailing for an average of five shillings, a substantial sum, even for the well-off. 4 Silver medals cost three times as much as than copper ones, and gold ones about fourteen times as much as than silver ones. Advertisements in the London papers suggest lower-value medals could be purchased at goldsmiths or bookshops. The exact details are murky, but pro-

Artifacts for a Future Past (Aldershot, U.K., 2015); Louis Marin, “The Inscription of the King's Memory: On the Metallic History of Louis XIV," Yale French Studies 59 (1980): 17-36; Alison Saunders, "Spreading the Word: Illustrated Books as Political Propaganda in Seventeenth-Century France," in Print and Power in France and England, 1500-1800, ed. David Adams and Adrian Armstrong (Aldershot, U.K., 2006), 69-84.

2. Neil Guthrie, The Material Culture of the Jacobites (Cambridge, 2013); Murray Pittock, Material Culture and Sedition, 1688-1760: Treacherous Objects, Secret Places (Basingstoke, U.K., 2013); Noel Woolf, The Medallic Record of the Jacobite Movement (London, 1988).

3. Kevin Sharpe, Rebranding Rule: The Restoration and Revolution Monarchy, 1660-1714 (New Haven, Conn., 2013); James Anderson Winn, Queen Anne: Patroness of Arts (Oxford, 2014). 4. All medal values are taken from A List of the Medals Struck in the Reign of Her Late Majesty, Queen Anne; With Their Price ([London, 1718?]). On buying power and relative income, see Robert D. Hume, “The Economics of Culture in London, 1660-1740," Huntington Library Quarterly 69 (2006): 487-533; Hume, "The Value of Money in Eighteenth-Century England: Incomes, Prices, Buying Power-and Some Problems in Cultural Economics," Huntington Library Quarterly 77 (2014):373-416. 
prietors probably bought wholesale from the Mint and made a small profit. 5 Usually only a very limited number of gold medals were cast. Most if not all of those would have been reserved for recognition of service or diplomatic gifts. For instance, in 1714 the Whig agent and publisher John Dunton received a large gold medal worth an astonishing thirty pounds for services to the new king, George I. ${ }^{6}$ Dunton proudly wore the token on a chain around his neck for several years until poverty eventually forced him to pawn it for cash. ${ }^{7}$

This episode tells us much about the value and use of medals in the period. For example, the scrap value of precious metal meant the gold and silver pieces had an intrinsic worth. An unfortunate offshoot was that medals were thus perfect targets for thieves. Small and portable, they could be taken easily and melted down or sold on the black market. Newspapers from the period are littered with advertisements for lost or stolen medals, usually with a hefty reward for their return. Indeed, the size of those rewards suggests medals were, perhaps unsurprisingly, worth far more than their scrap value. In the summer of 1706 , for example, a huge reward of thirty guineas was put out for the return of a five-guinea coin and a gold coronation medal from 1702, worth four pounds. ${ }^{8}$ The reward for the pieces was set at nearly double their market price, suggesting the coronation medal had some extra sentimental or political value. Little wonder Dunton was heartbroken at having to part with the medal bestowed on him by the king. Although Dunton was unusual in wearing a gold medal around the neck-such valuable items were usually locked away in display cabinets-extant specimens indicate it was common practice to pierce copper and silver medals so that they might be threaded with a ribbon or chain. When worn, medals were a public expression of allegiance to the current administration, or, in the case of Jacobite medals, to an alternative regime. Some medals were produced with a hole for this purpose, most notably the small gold tokens bestowed as part of the royal touch ceremony. 9 Medals were so

5. See Antony Griffiths, "Advertisements for Medals in The London Gazette," The Medal 15 (1989): 4-6; C. H. L. George, "Marketing Medals in Early Modern Britain: Advertisements for Medals of Charles V of Lorraine and Charles III 'King of Spain,"” The Medal 42 (2003): 23-26; George, "Medal Advertisements and the Glorious Revolution: A Previously Unknown Notice by George Bowers," The Medal 43 (2003): 20-22; and George, "Topical Portrait Print Advertising in London Newspapers and The Term Catalogues, 1660-1714" (PhD thesis, Durham University, 2005), 181-84.

6. John Dunton, The Medal: or, A Loyal Essay Upon King George's Picture (London, 1715). On medals as a reward for service, see The Cambridge Edition of the Works of Jonathan Swift, ed. Ian Gadd et al., 17 vols. (Cambridge, 2008-), 2:155.

7. Quoted in J. Yeowell, "Notes on Books and Men by Edward Harley, Earl of Oxford," Notes and Queries 9 (1860): 417-21.

8. London Gazette 4275 (October 31, 1706) and 4276 (November 4, 1706); Daily Courant 1434 (November 18, 1706); see also London Gazette 3814 (June 1, 1702).

9. On Samuel Johnson's “touch-piece," see Neil Guthrie, "Johnson's Touch-Piece and the 'Charge of Fame': Personal and Public Aspects of the Medal in Eighteenth-Century Britain," in The Politics of Samuel Johnson, ed. Jonathan Clark and Howard Erskine-Hill (Basingstoke, U.K., 2012), 90-111 at 90-94. On doubts over the authenticity of the British Museum touch-piece, see Helen Farquhar, "Royal Charities," British Numismatic Journal 15 (1919): 141-84 at 144-45. On the royal touch, see Stephen Brogan, The Royal Touch in Early Modern England (Woodbridge, U.K., 2015); Marc Bloch, The Royal Touch: Sacred Monarchy and Scrofula in England and France (London, 1973). 
effective as loyalist symbols that one anonymous moralist even complained many "hold it a less Sin to Revere a Monarch on a Medal, than our Saviour hanging on the Cross." ${ }^{10}$ Such object-worship came dangerously close to popery.

Medals would have taken a battering in their day-to-day use. But this physical deterioration did not lessen their value; when a "much bruised" gold medal was lost in January 1708, its owner nonetheless put out a two-guinea reward for its return. ${ }^{11}$ And access to medals was not limited to those who owned them. The vast majority who could not afford these official medals would still have been aware of their designs. Sometimes cheap copies of official medals made of low-quality copper alloy-known as jetons-could be bought for a few pence from a street peddler. Even where knockoff jetons were not readily available, medals would have been passed around at taverns and coffeehouses, where they were frequently the subject of discussion. Back in 1661, for instance, Pepys recalled looking over some medals at the Three Tun Tavern in Charing Cross. ${ }^{12}$ This was probably no isolated example. The frequency with which newspapers commented on medal designs, and the ferocity with which they debated them, suggests a general familiarity with medals was taken for granted.

What was the cultural status of these objects in Anne's reign? Numismaticsthat is, the study of coins and medals - was a subject attracting major thinkers of the day. ${ }^{13}$ By the early eighteenth century, the study of numismatics had reached a turning point in England. Previously popular studies in Latin such as Jacques de Bie's Regum et Imperatorum Numismata (1677), Jacob Oisel's Thesaurus Selectorum Numismatum Antiquorum (1677), and John Selden's Liber de Nummis (1675, 1678, 1682, and 1692) were being replaced by commentaries in the vernacular. The most prominent examples of these new English works were John Evelyn's highly influential Numismata: A Discourse of Medals, Ancient and Modern (1697), James Coningham's A Critical Essay on the Modern Medals (1704), and, a little later, Joseph Addison's Dialogues Upon the Usefulness of Ancient Medals (1726). ${ }^{14}$ Less dryly academic in tone, these works were aimed as much at the amateur enthusiast as at the serious scholar. As Evelyn's and Coningham's titles suggest, contemporary medals enjoyed greater prominence in these vernacular works. Even Addison's title emphasizes the current utility of ancient objects. In part this shift to modernity reflected the concerns voiced in the querelle of the ancients

10. H[enry] W[aring?], Miscellanies: or, A Variety of Notion and Thought. Being a Small Treatise of Many Small Matters ([London], 1708), 1.

11. Daily Courant 1843 (January 12, 1708).

12. The Diary of Samuel Pepys, ed. Robert Latham and William Matthews, 11 vols. (London, 1970-83), 2:206.

13. See Barbara M. Benedict, "The Moral in the Material: Numismatics and Identity in Evelyn, Addison, and Pope," in Queen Anne and the Arts, ed. Cederic D. Reverand (Lewisburg, Penn., 2015), 65-83; Guthrie, "Johnson's Touch-Piece and the 'Charge of Fame."”

14. Although the Dialogues was not published until well after Addison's death in 1719, the manuscript was mostly completed in Vienna in 1702. In the octavo edition of his 1735 works, Pope writes that "Mr. Addison intended to publish his Book of Medals" in 1715: The Works of Alexander Pope, Esq., 2 vols. (London, 1735), 2:64. Also, Edmund Curll referred to it in 1715 as "a Work well worthy to be made Publick" in his pirated edition of Louis Jobert's The Knowledge of Medals (London, 1715), 156; see Paul Baines and Pat Rogers, Edmund Curll: Bookseller (Oxford, 2007), 126. 
and moderns in the 1690 . ${ }^{15}$ But it also resulted from the surge in interest that accompanied the expansion of state medal-making in the first decade of the eighteenth century.

In addition to discussing the theory and practice of numismatics, these books put forward an agenda for modern medallurgy. We know Newton read Evelyn's $\mathrm{Nu}$ mismata: his personal copy is heavily dog-eared. ${ }^{16}$ Newton must also have been aware of Coningham's Critical Essay, which recognized the importance of medals that "have the Stamp of Authority, and the Prince's Person upon them" as politically charged images of the monarch. ${ }^{17}$ For Coningham, the medals of ancient Rome achieved this perfectly. Most importantly, they were "intelligible" and the "Reverses clearly represent to us the Intention of the Prince." By contrast with the clarity of ancient medals, which communicated the prince's "Intention" to the public, the designs of the previous century are "generally so unnatural, that the occasion of the Medal cannot be known by it." 18 "[W] hat a great Subject our Medallists have here to employ themselves in," he said, referring to the queen. ${ }^{19}$ The superiority of Anne's early medals, which Coningham deemed close in quality to those of ancient Rome, promised a reverse in the fortunes of medallic royal representations.

Clarity of message was vital. Although we now think of medals as material artifacts, at the time they were thought of in textual terms. ${ }^{20}$ Influenced by the celebrated classical scholar Richard Bentley, John Evelyn advocated a philological approach to coins and medals. ${ }^{21} \mathrm{He}$ described them as "Vocal Monuments" that, like classical texts, "require particular Explication." 22 Coningham wrote that similar features might "be

15. See Joseph M. Levine, The Battle of the Books: History and Literature in the Augustan Age (Ithaca, N.Y., 1991).

16. John Harrison, The Library of Isaac Newton (Cambridge, 1978), 141. According to one perceptive eighteenth-century annotator of the work, Numismata was written "chiefly to persuade that we are not the inferiour to the Dutch in metallic history, tho' we not be so frequent in the striking them as the Germans, nor to flatter by them as the French or Spaniards, nor indeed as James $2 \mathrm{~d}$ after his $2 \mathrm{~d}$ marriage here": John Evelyn, Numismata: A Discourse of Medals, Ancient and Modern (London, 1697), f ${ }^{\star}$ EC65.Ev226.697n (B), Houghton Library, Harvard University. These remarks are taken from the annotated title page.

17. John Coningham, A Critical Essay on the Modern Medals, With Some Reflections on the Taste and Judgment of the Ancients (London, 1704), sig. A6v.

18. Ibid., 19-20.

19. Ibid., sig. A8r.

20. See Vivienne Jones, "Poetry and Medals," The Medal 32 (1998): 39-43; and Sean Kellen, "Exemplary Metals: Classical Numismatics and the Commerce of Humanism," Word and Image 18 (2002): 282-94.

21. On Bentley's influence over Numismata, see Levine, The Battle of the Books, 338-42. Bentley's reputation has suffered over the years, primarily due to his work editing Paradise Lost and his characterization by Pope as the grumpy pedant Aristarchus. For a corrective of this view, see Kristine Haugen, Richard Bentley: Poetry and Enlightenment (Cambridge, Mass., 2011).

22. Evelyn, Numismata, 1, 64. Evelyn had previously emphasized the literary quality of medals in a letter from August 1689 to Samuel Pepys, in which he describes a good medallic collection as "a most necessary" feature of a well-stocked library: see Diary and Correspondence of John Evelyn, ed. William Bray, 4 vols. (London, 1850), 3:434-56. Kate Loveman makes little reference to medals in her recent examination of Pepys's library: Samuel Pepys and His Books: Reading, Newsgathering, and Sociability, 1660-1703 (Oxford, 2015). 
found both in Poetry and Medals," an observation also made by John Pointer, the chaplain of Merton College, Oxford, who described the "great Affinity between Coins and Poems." 23 Joseph Addison, in his celebrated Dialogues on the topic, wittily remarked that one "may often find as much thought on the reverse of a Medal as in a Canto of Spenser." 24 This was probably intended as a reflection on Spenser as much as on medals. But the important point here is that medals and coins were not just being looked at, they were being read. Just as a panegyric poem could be misinterpreted and politicized by readers, medals, too, could be a potentially tricky mode of royal praise when executed poorly or by the wrong people, as Addison and others recognized. ${ }^{25}$ As with poetry, the challenge is to work out the relationship between the intended message of a medal and the broader repercussions of its likely topical resonance.

It is difficult to calculate precisely how many medals were produced by the Mint for the Crown in the latter part of the seventeenth century. ${ }^{26}$ Besides the Roettier brothers, who were in charge of most official commissions, Charles II and James II also patronized several commercial medallists working in London at the time. Likewise, William III continued to have medals produced for him by celebrated Dutch engravers, such as Jan Smeltzing. Working out the exact relationship between these regimes and the production of medals is all but impossible without significant new evidence. The paperwork from Anne's reign, on the other hand, survives and has been well discussed by Peter Barber. ${ }^{27}$ During her twelve years on the throne, the Mint produced twenty-nine individual medals. Compare this to just nine medals produced for George I in his fourteen-year reign. As medals were produced on royal or ministerial

23. Coningham, A Critical Essay on the Modern Medals, 17; John Pointer, Britannia Romana: or, Roman Antiquaries in Britain (Oxford, 1724), sig. A1v.

24. Joseph Addison, Dialogues Upon the Usefulness of Ancient Medals. Especially in Relation to the Latin and Greek Poets (London, 1726), 15. Addison's protégé Thomas Tickell later used medallic imagery in his bestselling panegyric On the Prospect of Peace (London, 1712):

here the Ore, whose melted Mass shall yield

On faithful Coins each memorable Field,

Which, mix'd with Medals of immortal Rome,

May clear Disputes, and teach the Times to come.

In circling Beams shall Godlike ANNA glow,

And Churchill's Sword hang oer the prostrate Foe.

$$
\text { (9-10) }
$$

25. On the political application of verse in this period, see Alan Roper, "Drawing Parallels and Making Applications in Restoration Literature," in Politics as Reflected in Literature: Papers Presented at a Clark Library Seminar, 24 January 1987, ed. Richard Ashcroft and Alan Roper (Los Angeles, 1989), 29-65; John M. Wallace, "Dryden and History: A Problem in Allegorical Reading," English Literary History 36 (1969): 265-90; Wallace, “'Examples Are Best Precepts': Readers and Meanings in SeventeenthCentury Poetry," Critical Inquiry 1 (1974): 273-90. For a similar approach to opera, see Robert D. Hume, “The Politics of Opera in Late Seventeenth-Century London," Cambridge Opera Journal 10 (1998): 15-43.

26. Edward Hawkins catalogues the full scope of "medals" in the period, ranging from examples produced abroad to unofficial tokens, jetons, and badges: Medallic Illustrations of the History of Great Britain and Ireland to the Death of George II, ed. Augustus W. Franks and Herbert A. Grueber, 2 vols. (London, 1885).

27. Peter Barber, "Commemoration and Control: The Design and Issue of Official Commemorative Medals in England, 1704-13," The Medal 6 (1985): 2-5. 
orders, the significant difference in output reflects the shifting priorities of the two regimes. Needless to say, Anne was far more interested in her public image than her successor. Prior to manufacture, proposed medal designs had to be approved by Treasury officials. The approval process was long and convoluted. As Lord High Treasurer, Sidney Godolphin was at the center of this process until his ousting by Robert Harley in 1710. Consulting with the queen on proposed designs, the Lord High Treasurer would relay any necessary adjustments to Newton before offering his approval. We know from correspondence between Godolphin and Newton that Anne was personally interested in her medallic representation and took her time examining the designs. ${ }^{28}$ Godolphin would also consult appropriate dignitaries on proposed designs for medals; annotations in the hand of William Lloyd, bishop of Worcester, exist on a design submitted to the Lord Treasurer by Newton. ${ }^{29}$ After this, the finalized design needed to be signed off on by the master, warden, and comptroller of the Mint before production could begin.

\section{$\sim$ Newton's Medal Designs}

Newton's career in the Mint began in the spring of 1696. He was appointed to the post of warden at the recommendation of his friend Charles Montagu, the first Earl of Halifax, who was at that time chancellor of the Exchequer. In 1699 the mastership became vacant. Moving quickly, Newton secured the post to supplement his income. Generally, the positions of warden and master were considered sinecures, but Newton took an active role. His campaigns against busy clippers and counterfeiters, and the complex calculations behind his coinage policies, have all been well documented. $3^{\circ}$ All this time, too, he was regularly standing in parliamentary elections as the Whig candidate for Cambridge, although he was only elected twice, in 1689 and in $1701 .{ }^{31}$ Newton was no political innocent; we need to bear in mind how his political allegiance may have shaped the designs he produced for the "Tory" queen. As master, Newton was inducted into the world of medallic design. His predecessors had left this job to the engravers and medallists. Newton considered the designing of medals important enough to warrant his personal attention. Generally speaking, though, Newton did not meddle with the design of coinage. Such changes as he did make were technical, to prevent coins' being forged or tampered with. Whereas fiscal policy and investigation of fraud engaged Newton's genius for mathematics and puzzles, medal design gave him an opportunity to put the historical, mythographical, and political aspects of his learning to use. ${ }^{32}$

28. The Correspondence of Isaac Newton, ed. H. W. Turnbell et al., 7 vols. (Cambridge, 1959-77), 4:429. Hereafter Correspondence.

29. The Manuscripts of His Grace the Duke of Portland, Preserved at Welbeck Abbey, Historical Manuscripts Commission, 10 vols. (London, 1891-1931), 4:151.

30. The only full-length account of Newton's career at the Mint is Sir John Craig, Newton at the Mint (Cambridge, 1946). See, too, Thomas Levenson, Newton and the Counterfeiter: The Unknown Detective Career of the World's Greatest Scientist (London, 2009).

31. For Newton's political career, see The History of Parliament: The House of Commons 1690-1715, ed. Eveline Cruickshanks, Stuart Handley, and D. W. Hayton, 5 vols. (Cambridge, 2002), 4:1025-27.

32. See Jed Z. Buchwald and Mordechai Feingold, Newton and the Origin of Civilization (New Haven, Conn., 2012). 
Designing medals was a collaborative process. When preparing a coronation medal for George I in 1714, for instance, Newton solicited help from both his great friend the physician and poet Sir Samuel Garth and his protégé at the Mint, Hopton Haynes. 33 The master also worked closely with his chief engraver, John Croker. A German immigrant, Croker had learned his craft in Dresden before moving to London in 1691. From 1697 he was responsible for virtually all medallic commissions at the Mint, prior to his appointment as chief engraver in 1705.34 Newton and his colleagues were responsible for the ideas behind medal designs. Croker's task was to turn those ideas, however abstract, into a coherent image. In return, Croker would have vetoed any proposals too complex or obscure to execute, and he put forward ideas of his own. David Pickup has suggested that Croker was the "designer" and that Newton, in his role as master, only approved or amended designs at a later stage. 35 It is difficult to reconstruct their working relationship, as a great deal was communicated informally; they shared sketches and discussed ideas in person as much as in writing. The paperwork we do have, though, indicates the actual process was far more collaborative than Pickup allows. Generally speaking, it appears that Newton suggested ideas and sometimes drafted rough sketches for Croker, who would polish the designs before submitting them for Newton's approval. The Master would then suggest any final changes and request approval from the queen and her ministers before setting the engraver to work.

Newton's Mint papers also reveal much about his own working practices. Ideas for designs are interleaved with—and often jotted in the margins of-pages of complex sums or biblical chronology. Possible subjects for George I's coronation medal mingle with both calculations relating to the Principia and notes on Persian history. ${ }^{36} \mathrm{New}$ ton's chronological scholarship, of which his work on Persian history was a part, influenced his approach to designing medals. This is most apparent in his first foray into design, for the reverse of Anne's coronation medal (fig. 1). Medals had been an important feature of the coronation ceremonial since 1547.37 As convention demanded, upon Anne's coronation 1,200 silver medals were "thrown about" Westminster Abbey as a demonstration of royal largesse, and 300 gold medals were bestowed on the Lords when they swore allegiance to their new queen..$^{8}$ Due to tight finances, a further 518 gold

33. For Haynes's and Garth's suggestions, see Mint 19/3, fols. 309-11, The National Archives, Kew (hereafter TNA); Haynes's suggestions are also reprinted in Correspondence, 6:175-76. Where edited versions of Newton's manuscripts are available in the Correspondence, references are given to that edition.

34. For Croker, see Christopher Eimer, An Introduction to Commemorative Medals (London, 1989), 20-24.

35. David Pickup, "John Croker and the Alchorne Manuscript," The Medal 20 (1992): 19-31 at 19-21.

36. TNA, Mint 19/3, fol. 316; TNA, Mint 19/5, fol. 31 .

37. On Edward VI's coronation medal, see Kevin Sharpe, Selling the Tudor Monarchy: Authority and Image in Sixteenth-Century England (New Haven, Conn., 2009), 232-33.

38. The Post Boy 1083 (April 25, 1702); The Post Man 960 (April 25, 1702); The Flying Post 1086 (April 23, 1702); TNA, Mint 19/3, fol. 336. On coronation medals in the period more generally, see Carolyn A. Edie, “The Public Face of Royal Ritual: Sermons, Medals, and Civic Ceremony in Later Stuart Coronations," Huntington Library Quarterly 53 (1990):311-36; David Pickup, "While the Bright 

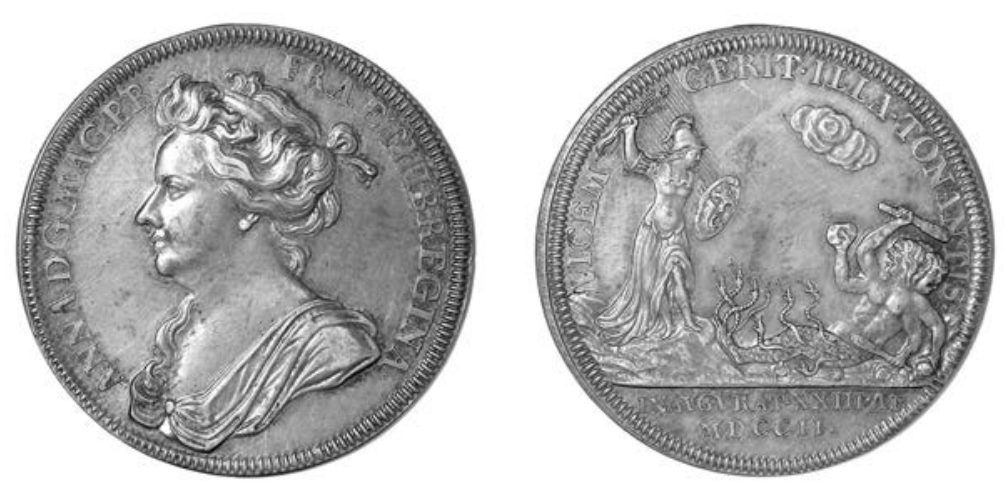

FIGURE 1. Isaac Newton and John Croker, medal for coronation of Queen Anne (1702). ( ) Trustees of the British Museum, G3,EM.39.

medals for the Commons were "made afterwards" and delivered to Harley for distribution; forty "double"-sized gold medals were reserved as gifts for "foreign Ministers and Persons of quality."39

The standard gold and silver medals showed, on the obverse, a bust of Anne with her hair bound in a ribbon, modeled on a portrait by Sir Godfrey Kneller. $4^{\circ}$ The reverse was based on the first of three designs proposed by Newton. The other two he considered were Pallas in armor with the motto "Virtute et Consilio," meaning, "courage and counsel," and "Virgils metallic Tree with a golden branch \& this motto Non deficit alter." The latter image and motto are taken from book 6 of the Aeneid, in which Aeneas, before venturing into the underworld, pulls a branch from the golden bough, and another grows immediately in its place. According to Newton, "The Tree is an emblem of a kingdome \& the principal branch is the King or Queen \& the springing out of a new golden branch as often as the old one is cropt off is a type of a lasting Monarchy." ${ }^{41}$ The allegory was probably too obscure for the purpose at hand. Besides, it was not specific enough to Anne; the same symbol could apply to any royal succession. The finished medal represents the queen as Pallas Athene, goddess of wisdom and war. She stands ready to hurl a thunderbolt at a double-headed, four-armed monster with legs sprouting snakes. Newton's notes and reports in the newspapers identify the

Coins in Silver Showers Descend': British Coronation Medals of the Seventeenth-Nineteenth Centuries," The Medal 44 (2004): 26-29; Janet Snowman, "King and Country: The Coronation Medals of George III," The Medal 47 (2005): 23-41. There are jeton imitations of this medal (items M.7992M.7995, M.9279, and 1870,0507.16051, British Museum [hereafter BM]) and also copies made by the German medallist Christian Wermuth (BM, items M.7990-M.7991).

39. TNA, Mint 19/3, fol. 336r; see The Flying Post 1086 (April 23, 1702).

40. The portrait is number 46 in J. Douglas Stewart's catalogue raisonné of Kneller's works: Sir Godfrey Kneller and the English Baroque Portrait (Oxford, 1983), 91.

41. TNA, Mint 19/3, fol. 297r. 
monster as a "gyant." ${ }^{22}$ Newton was thinking of the Gigantomachia-that is, the war between the classical pantheon and the Titans. In particular, he had in mind Briareus or Aegaeon, whom he describes in The Chronology of Ancient Kingdoms Amended (1728) as "a Giant with 50 heads, and an hundred hands." 43 The legend reads "vICEM. GERIT. ILLA. TONANTIS.," which translates as "she is the vicegerent of the thunderer." Like the coronation medals of Anne's predecessors, the design is highly emblematic. Newton deployed classical mythology as topical allegory, evoking both Anne's right to the throne and her aggressive foreign policy.

Newton's papers show he was alive to the political circumstances of Anne's accession while designing her coronation medal. Anne's claim to the throne came from the 1689 Bill of Rights and the 1701 Act of Settlement, which stipulated that, upon her death without an heir of her body, the Crown should pass to her cousin Sophia, the Protestant Electress of Hanover, and not to Anne's Catholic half-brother, James Francis Edward Stuart. In other words, Anne claimed the throne by statute, not by common law. Aware that emphasizing Anne's Stuart lineage would lend itself to a Jacobite interpretation, which the queen and her ministers were naturally keen to avoid, Newton instead decided to foreground the statutory dimension of her succession. He achieved this by alluding to the iconography of William and Mary's coronation medal from 1689 , designed and cast by John Roettier. That medal's reverse shows a scene from classical mythology. From a cloud Jupiter hurls a thunderbolt at Phaeton, who falls from his chariot. The motto is succinct: “NE. TOTUS. ABSUMATUR.," meaning, "lest everything be lost." Jupiter represents William. Phaeton has lost control of the reins of power and thus stands in for James II, who had fled the country following William's invasion in November 1688. The image provides a neat allegory of the Glorious Revolution. But the sun deity also recalls the iconography of James's cousin, Louis XIV, who was harboring the fugitive monarch and newborn "Prince of Wales" in his palace at SaintGermain. We thus also get a hint of William's bellicose foreign policy toward France.

In order to cast Anne as William's constitutional successor, Newton depicts her as Pallas Athene, the favorite daughter of Jupiter. 44 The mythic genealogy links the two medals and thus the two rulers. There are other symbolic connections between the medals. In his exposition of the design, Newton notes that the "Thunderer" of the motto relates to William III, "for Thunder signifys War, \& that King was a Warriour all

42. The Post Man 951 (April 4, 1702). Most recent scholars have erred in identifying this monster as a "hydra." This misinterpretation stems from Abel Boyer, who describes the supposed "hydra" on Anne's coronation medal as "the Emblem of Rebellion, Sedition, Schism, Heresey, \&c." in his History of the Life and Reign of Queen Anne, Illustrated with all the Medals Struck in this Reign (London, 1722), 718 .

43. Isaac Newton, The Chronology of Ancient Kingdoms Amended (London, 1728), 226-27. For Newton's take on the Gigantomachia, see Buchwald and Feingold, Newton and the Origin of Civilization, 379. The Gigantomachia had previously featured on a medal for Charles II, engraved by George Bower around 1660 .

44. Pallas had previously featured in William's medallic iconography: see Sir Mark Jones, “The Medal as an Instrument of Propaganda in Late Seventeenth- and Early Eighteenth-Century Europe," Numismatic Chronicle 142 (1982): 117-26 at 119. 
his life-time." 45 This account of the symbol echoes his work in the Chronology on the historical image of Jupiter, who in antiquity was always depicted holding "a Thunderbolt to represent him a warrior." 46 On the 1702 medal, the thunderbolt is grasped by Pallas-that is, by Anne. The "gyant" is likewise emblematic. It represents, in Newton's words, "any Enemy with which Her Majesty hath or may have War." 47 The multiple heads and hands signify entire nations; as Newton put it in his first notes on the design, the mythic giants are "bodies politic." 48 But the monster's two faces might also allude to the double Catholic threat of Louis XIV and James Francis Edward Stuart. In this respect, the medal shows Anne continuing the war started by her predecessor.

The motto also "relates to the last Coronation medal" and thus speaks to the constitutional dimension of Anne's succession of William.49 In an explanation of its symbolism - written in a trained scribal hand and likely presented to the queen for her approval-Newton provides a politically charged translation of the Latin motto: "She is God's Vicegerent, \& K. W.ms Successour." 50 His annotations on a draft presentation copy expand this politicized translation: "Under God She reigns \& makes war in K. W.ms stead." 51 He explains that the coronation medal "signifys that her Majesty continues the Scene of the last Reign." 52 By recalling William's medallic iconography, Newton elides Anne's potential status as heir to her deposed father. The medal thus associates the queen with the Revolution Settlement while distancing her from the illegitimate claim of her half-brother.

This design had a distinct partisan coloring. The medal's emphasis on the Revolution Settlement makes an emphatically Whiggish statement. And outright war with France was likewise considered a Whig policy; mindful of the costs involved and remembering the inflated taxes of the 169os, High Tories like Rochester instead advocated investing in a strong navy, which they perceived as a cheaper option. Admittedly, though, most moderate Tories supported the queen's decision to pursue war against France. As an established Whig agent, Newton must have realized the valence of the design. Without new evidence, the following point cannot be anything more than conjecture. These official documents point toward Newton smuggling a Whig message onto the coronation medal. If my suspicion is correct, then his intention was not just to provide the queen with a strong public image but also to score points for his party. The medal's status as a royally sponsored object lent its message legitimacy while also affording its designer plausible deniability. The coronation medal appeared with the queen's authority, and, beyond the Mint, Newton's role was unknown.

45. TNA, Mint 19/3, fol. 289.

46. Newton, Chronology of Ancient Kingdoms, 226.

47. TNA, Mint 19/3, fol. 289.

48. Ibid., fol. 297.

49. Ibid., fol. 289.

50. Ibid. Seven drafts of this document exist in Newton's hand: see fols. 291-96, 298-300. The hand of the presentation copy is probably that of Hopton Haynes.

51. Ibid., fol. 301.

52. Ibid., fol. 289. 
Newton was also responsible for another " 40 Medals of Gold (most of them double ones) for forreign Ministers \& Persons of quality." 53 No examples of Anne’s coronation medal exist at this "double" size; perhaps they were melted down or lost. There is, however, another possibility. Numismatists have long puzzled over a large undated medal from Anne's reign, known as the Palladium, which represents the queen as Pallas with the motto "NOVAE. PAlladium. TroiaE.," alluding to the statue of Athene on which the safety of Troy was said to depend in the Iliad (fig. 2). The eighteenth-century Flemish numismatist Gerard van Loon suggested that this medal was produced to commemorate the accession. But, as Arjan van Gemund, Edward Hawkins, and others have since pointed out, the existing warrant for its production was signed on February 20,1707 , indicating it was probably struck to mark the union of England and Scotland. Besides, the obverse portrait of the queen on extant examples of the Palladium is of a style more consistent with other medals from 1707 and 1708. And yet, as David Pickup has shown, official Mint paperwork lists the Palladium between the coronation medals and the accession medals, suggesting they are contemporaneous. 54 Newton's papers have not featured in the discussion. Their evidence is unclear, but one possibility they raise is that the Palladium was originally struck for Anne's coronation and then reissued to commemorate the Union of England and Scotland in 1707.

We know medals were often re-struck. For instance, a double-portrait medal of Anne and her consort, Prince George of Denmark, originally produced in 1702, was recommissioned in 1707, as was the 1704 medal commemorating Queen Anne's Bounty in November 1711.55 If it was originally produced in gold for Anne's coronation, the medal may then have had a different obverse, more fitting with medallic portraits of the time. Puncheons and dies frequently got damaged in the manufacturing process, or even in storage. Perhaps the original obverse die was in no condition to be reused in 1707, and thus Croker crafted a new one more fitting with Anne's current image. Alternatively, he may simply have decided the reissued medal should have an updated portrait of the queen..$^{6}$ To the best of my knowledge, no examples of the Palladium survive in gold. And yet we know from Mint papers they existed. As diplomatic gifts, they would most likely have been dispersed across Europe and are probably now in the hands of private collectors or were melted down long ago. If fewer than forty were originally made, as Newton writes, then less than a handful might have survived. Later valued at thirty pounds, making it by far the largest medal of Anne's reign, the gold Palladium is the only medal that fits the bill. Furthermore, its diameter is exactly double that of the standard coronation medals, which fits perfectly with Newton's description. When taken together with its position in the printed chronology of medals produced by the Mint, it seems highly likely that the Palladium,

53. Ibid., fol. 336.

54. Pickup, "John Croker and the Alchorne Manuscript," 23.

55. Add. MS 18757, fols. 4r, 13r, British Library (hereafter BL).

56. Croker's sketch of the reverse differs slightly from the finished medal. It is quite possible that the 1702 version of the medal bore more resemblance to the drawing and that it was altered in 1707. See Pickup, "John Croker and the Alchorne Manuscript," 22-23. 

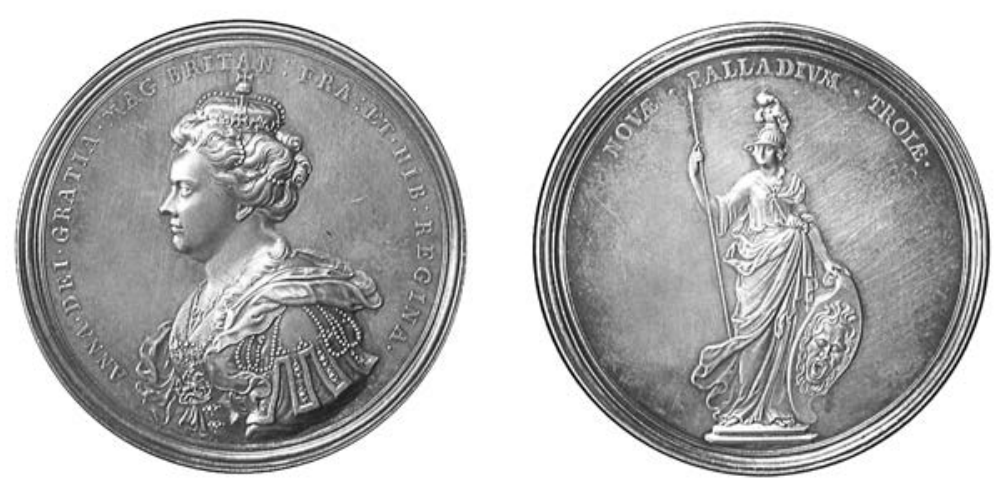

FIGURE 2. Isaac Newton and John Croker, Palladium medal for coronation of Queen Anne / Act of Union (1702/7). (C) Trustees of the British Museum, G3,EM.93.

or an earlier version of it with a different obverse, was the "double" medal reserved for visiting grandees.

Certainly, the Palladium would have made an excellent diplomatic gift. Not only was it exquisitely wrought and inherently valuable, but it also conveyed an important political message. Anne's accession medal had taken its legend, "ENTIRELY ENGLISH," from her dramatic first speech to Parliament, in which she proclaimed, "I know mine own Heart to be entirely English." 57 This was read by many as a reflection on the Dutch William III, whose foreignness had not endeared him to the patriotic English. Naturally, Dutch ambassadors were worried about the likely direction of the new queen's foreign policy following this isolationist rhetoric. The Palladium medal was designed to win back their trust. The new Troy referenced in the motto was the Grand Alliance of England, Holland, and the Holy Roman Empire: Anne is a Palladium keeping those nations safe from the encroachments of France. Certainly, that is how the medal was interpreted by eighteenth-century numismatists, such as Paul Rapin de Thoyras (also an eminent historian) and Johann Hieronymus Lochner, who in 1744 described the Palladium as "showing the great importance of the queen to the alliance of the time." 58 It should come as no surprise that the master proposed to reissue this particular medal in 1707 in order to mark a new political union.

As we have seen, Newton's interest in medal design was shaped by scholarship and politics, which were, for him, inseparable. Newton had plans to develop Anne's mythic image as a "thundering" Pallas in further medals. When designing a medal to commemorate Ormond and Rooke's naval victory at Vigo Bay in late 1702, for example,

57. The History and Proceedings of the House of Commons, 5 vols. (London, 1742), 3:197-98.

58. Johann Hieronymus Lochner, Samlung Merkwürdiger Medaillen (Nuremburg, 1744), as cited in Pickup, "John Croker and the Alchorne Manuscript," 23. For de Thoyras's comments on the medal, see The Metallick History of the Reigns of William III and Queen Mary, Queen Anne and King George I (London, 1747), 1. 
he proposed to "pursue the humour of the Coronation Medal \& explain \& justifie it" by illustrating a "a very proper passage in Virgil when the Poet is describing how Pallas overthrew the ships of the Greecians by a storm of thunder." 59 The proposal was accompanied by rough, half-finished sketches in Newton's hand. These plans show that, early in the reign at least, Newton had in mind a sustained medallic image for Anne as a "thunderer," rivaling Louis XIV's Sun King iconography. Thunder was a doubly appropriate symbol for countering French propaganda. First of all, thunder symbolized a warrior, as Newton explains in the Chronology and also in his notes on the coronation medal. Secondly, Dutch medallists had previously used clouds to blot out the Sun King. ${ }^{60}$ The use of thunderclouds was the logical next step.

By recalling the iconography of the coronation medal in later medals, Newton was conceiving them as part of the same project rather than as individual objects. This was entirely new to English medallurgy. Of course, previous Stuart medals had used recurring symbols, such as the oak, and scenes from classical myth also featured prominently. But no English monarch had an ongoing medallic persona like the thundering Pallas image Newton was contemplating for Anne. This was a radical move clearly influenced by the example of Louis's Académie. The master's plans for a sustained campaign of medallic propaganda disseminating this image were never realized. Nonetheless, the victory at Vigo still provided a significant opportunity for numismatic propaganda. The fleet had brought back a small hoard of silver to be melted down and struck as the coming year's coinage. Anne issued Newton a warrant to inscribe "VIGO" in small but clear capitals on the obverse of all the new coins, below her effigy, so as to "continue to posterity the remembrance of that glorious Action." 61 From sixpences to five-guinea gold pieces, these coins were a reminder of English victory, associating the royal image with military strength.

It is impossible to say precisely why the project for Anne's sustained image as Pallas was shelved. Possibly the queen, Godolphin, or Croker were less enthusiastic than Newton. Or perhaps the proposal for a sustained medallic iconography was simply too close to the French example, although this seems unlikely. Either way, Newton and his colleagues chose a different approach. Instead of abstract iconography, like that of the coronation medal, Anne's other medals consistently show realistic scenes of battle or the aftermath of battle. Some literary critics have suggested this focus on the nature of warfare distances the reverse of medals from the queen's portrait on the ob-

59. TNA, Mint 19/3, fol. 305. The precise lines were Aeneid 1.39-43. Incidentally, Joseph Addison adapted a similar passage from the first book of the Aeneid for his own neo-Latin panegyrics on the Vigo operation, and may actually have recalled Anne's coronation medal in lines such as "i nunc et ritu Salico muliebria temne / imperia, Angliacae fulmina passa dea”: BL, Add. MS 37349, fols. 57-58. See Estelle Haan, Vergilius Redivivus: Studies in Joseph Addison's Latin Poetry (Philadelphia, 2005), 126-29.

6o. See Jones, “The Medal as Instrument of Propaganda," 202.

61. Correspondence, 4:404. Although the propagandists claimed a great victory at Vigo, the expedition was not a complete success. Spying the English fleet, the Spanish had sent much of their treasure inland: Philip of Anjou received almost all of his shipment of silver. English investors in the merchant vessels sunk in the operation suffered significant losses, and the amount of silver actually seized was relatively small. See Henry Kamen, “The Destruction of the Spanish Silver Fleet at Vigo in 1702," Bulletin of the Institute of Historical Research 39 (1966): 165-73. 

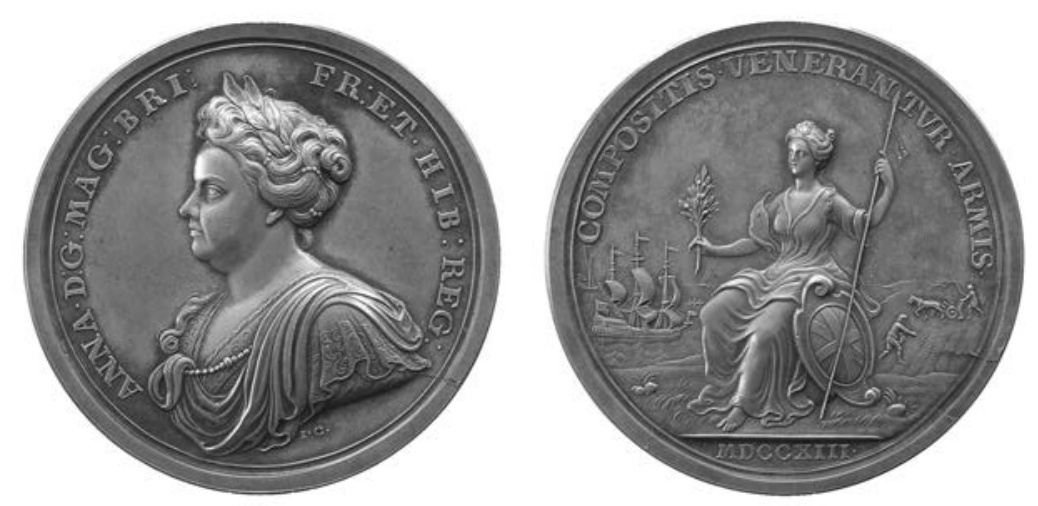

FIGURE 3. Isaac Newton and John Croker, medal for Peace of Utrecht (1713). ( ) Trustees of the British Museum, G3,EM.95.

verse, resulting in a "weak" public image. Toni Bowers, for example, has argued that Anne is "conspicuously absent" from the military victories celebrated on medals, which are "all-male events far removed from the ponderous, impassive queen depicted on the front of the coin." 62 That is simply false.

Anne is present on the reverses of her medals in repeated images of mythological and emblematic female figures. ${ }^{63}$ True, she is only depicted as queen on two medals, those marking Queen Anne's Bounty and the battle of Saragossa. But we do have detailed sketches in Croker's hand for unrealized medals depicting Anne enthroned. ${ }^{64}$ Besides, monarchs seldom appeared as themselves on the reverses of medals anyway. James II never appeared on the reverse of any of his official medals and, if we exclude examples struck in Holland, neither did William III. As it stands, Anne appears in half a dozen medals as the winged goddess Victory, overseeing the conduct of her troops fighting below. In other medals she is represented by Bellona or Pallas, as in the medal for the taking of Douai; by Britannia in the medals celebrating the battle of Blenheim and the Peace of Utrecht; or even by a hybrid of Bellona and Britannia, as in the medal commemorating the failed Jacobite invasion of Scotland in 1708. Indeed, on the Utrecht medal Britannia's appearance seems calculated to recall the image of the queen from the obverse: both have their hair bound in pearls with a single lovelock draped over the shoulder (fig. 3). ${ }^{65}$ Such visual similarities suggest Croker conceived Britannia as an emblem of the queen. These mythic guises were, of course, highly conventional in panegyric verse. Poets such as Nahum Tate, Richard Blackmore, and the young Alexander Pope all equated Anne with Britannia in their panegyrics. Likewise,

62. Toni Bowers, The Politics of Motherhood: British Writing and Culture, 1680-1760 (Cambridge, 1996), 78-79.

63. Sharpe, Rebranding Rule, 610.

64. See BL, Add. MS 18757, fols. 36v-37r.

65. James Anderson Winn has come to a similar conclusion in an essay published after this essay was completed: see his “'Like Her Britannia’s Self': Mythology and Politics in the Life of Queen Anne," Swift Studies 30 (2015): 31-70. 
the court playwright Peter Motteux in 1703 adapted John Dryden's opera King Arthur (originally 1691) to make the comparison: "Unmov'd she sits Majestick and serene / Like her Britannia’s self among the Isles a Queen." 66 It does not matter whether Newton and Croker adapted the discourse of panegyric to medal-making or simply arrived at the same iconographic strategies as the poets. Either way, the upshot was a mode of royal representation that successfully associated a sickly queen with the victories won by her generals.

Until now we have concentrated on the Mint's efforts to provide Anne with a strong medallic image and the political pressures that affected the production of that image. Sketches and notes reveal the calculation behind medal design. We must now turn to the resonance of Anne's medals and weigh their potential for political application and appropriation.

\section{$\sim$ Medals and Party Politics}

The partisan appropriation of medals goes back to the origins of parties. At the height of the Exclusion Crisis, the Earl of Shaftesbury's followers-labeled "Whigs" by their political opponents-wore medals to display their allegiance. The most famous of these was produced by George Bower after Shaftesbury was acquitted of treason in 1682. ${ }^{67}$ In his salvo against the Whigs, The Medal (1682), Dryden described how Bower's medal could be found strung round "the Necks of the lewd Nobles," that is, the seditious Whig lords. ${ }^{68}$ He neglects to mention the cheap jetons and badges that copied the design for Shaftesbury's lesser supporters. According to Pope, Dryden wrote The Medal at the behest of Charles II himself, suggesting the king considered Bower's Whig medal to be dangerously subversive. ${ }^{69}$ Some years later, an extensive medallic campaign accompanied the Glorious Revolution, legitimizing the new Dutch king in the public imagination. ${ }^{70}$ But these medals did not always have the desired effect. William and Mary's coronation medal (described above) was the subject of heavily politicized readings. One anonymous pamphleteer suggested that "the People knowing that this King and Queen had, not by Permission, but by Violence, Ascended their Fathers Throne, would look upon this as his Chariot which they drive, and interpret Jupiter's Thunder-bolt as a Sign of some Judgement of God impending

66. Winn, Queen Anne, 309.

67. See Anne Barbeau Gardiner, "Dryden, Bower, Castlemaine, and the Imagery of Revolution, 1682-1687," Eighteenth-Century Life 25 (2001): 135-46.

68. The Works of John Dryden, ed. H. T. Swedenberg et al., 20 vols. (Berkeley, Calif., 1956-20oo), 2:52 (line 299). For interpretations of Dryden's poem, see Phillip Harth, Pen for a Party: Dryden's Tory Propaganda in Its Contexts (Princeton, N.J., 1993), 168-89; Margaret Kingsley, "Dryden and the Consumption of History," in Enchanted Ground: Reimagining John Dryden, ed. Jayne Lewis and Maximillian E. Novak (Toronto, 2004), 31-51; Abigail Williams, Poetry and the Creation of a Whig Literary Culture, 1681-1714 (Oxford, 2005), 63-69; and James Anderson Winn, John Dryden and His World (New Haven, Conn., 1987), 363-70.

69. Joseph Spence, Observations, Anecdotes, and Characters of Books and Men, ed. James M. Osborn, 2 vols. (Oxford, 1966), 1:28.

70. Sharpe, Rebranding Rule, 434-37; Benjamin Weiss, "Medals of the Glorious Revolution: The Influence of Catholic-Protestant Antagonism," American Numismatic Society Magazine 13 (2014): 6-23. 
over our Gracious Prince."71 As these examples from the 1680 os demonstrate, writers on all sides could appropriate and deliberately misinterpret medals to make a polemical point.

By the time Anne came to the throne, the two-party system was entrenched. The passing of the Triennial Act in 1694 ensured that a general election would be held every three years, making election fever-and consequent party conflict-a permanent fixture of political life. This climate shaped the public reception of Anne's medals. Her coronation medal was one of the most politically divisive. This was in part due to the nature of this royal succession. Anne's image was not a fixed entity in the months between her accession and the opening of her first Parliament; both parties were fighting to represent her to the public as one of their own. ${ }^{72}$ The coronation medal furnished ammunition in this conflict. In his biography of Newton, Richard Westfall suggests that nobody could possibly have penetrated the allegorical messages coded in the design. 73 The evidence does not support this assumption. On the contrary, whereas modern scholars have been content to rely on a misreading of the medal peddled by Abel Boyer twenty years after the event, there is plenty to suggest that, at the time, the public understood Newton's allegory and were alive to its political application.

Anne's coronation medal was especially useful for Whigs, who capitalized on the partisan messages Newton coded into its design. Opportunistic Whig publicists, such as the prolific poets John Hughes and John Dennis, could allude to the medal in their efforts to refashion Anne as a Whig monarch ruling by revolution principles. In his elegy on William, for example, Hughes states that Anne "shall supply the Thunderers Place" and go to war against "the Giants impious Race," while Dennis argues, "if good Kings are God's Vicegerents, sure / A Tyrant is Hell's Viceroy."74 An anonymous poem circulated at the time also discussed the implications of the coronation motto in these terms:

\author{
If Mighty Jove's Auspicious Reign be o'er, \\ To thunder is alone in Anna's Pow'r: \\ Proud Ruling Tyrants her fierce Arms subdue; \\ Thunder she sends as well a Lightning too; \\ While 'twixt'em both a dire Eclipse is seen, \\ And Albion views a Goddess in a QUEEN,
}

71. A Letter from a Gentleman in the Country to his Correspondent in the City, Concerning the Coronation Medal, Distributed April 111689 (London, 1689), 2.

72. On the conflicting representations of Anne's accession, see Joseph Hone, "Politicising Praise:

Panegyric and the Accession of Queen Anne," Journal for Eighteenth-Century Studies 37 (2014): 147-57.

73. Richard Westfall, Never at Rest: A Biography of Isaac Newton (Cambridge, 1980), 622.

74. John Hughes, The House of Nassau: A Pindarick Ode (London, 1702), 12; John Dennis, The Monument: A Poem Sacred to the Immortal Memory of the Best and Greatest of Kings, William the Third (London, 1702), 9-10. An exception from later in the reign is a poem on the coronation medal by the Jacobite peer and poet George Granville, Baron Lansdowne: Poems Upon Several Occasions (London, 1712), 169; compare BL, Lansdowne MS 852, fol. 21v. Here it is deliberately ambiguous whom Lansdowne means by "the Thunderer." 
Which causes Gallia's Sun to disappear, And ANNA's Arms proclaim the Thunderer. ${ }^{75}$

Here, as in Hughes's poem, "Mighty Jove" is unquestionably William III; like Newton, the poets pick up on iconography recycled from the coronation medal of 1689 . According to these poets, Anne comes to the throne as the heir to her brother-in-law. The anonymous poem also picks up more generally on aspects of the medal: the English have "a Goddess" for "a QueEn," who subdues "Proud Ruling Tyrants." As well as a swipe at her father, James II, this is clearly an allusion to the absolute rule of Louis XIV. Hughes and Dennis have the same target in mind when they discuss the "Giants impious Race" and "Hell's Viceroy." Anne's military strength brings about a "dire Eclipse" that extinguishes "Gallia's Sun," recalling and then overpowering the Sun King motif of Louis's medals.

That Tory writers pointedly omit to mention the medal in any of their many panegyrics is telling. ${ }^{6}$ Seeing as medallic iconography could be interpreted in multiple ways, we might expect Tories to have seen the many-headed giant as an emblem of the schismatic domestic mob.77 That they did not suggests that Whig interpretations of the coronation medal had become entrenched. Indeed, our only record of the Tory response probably comes from the Whig polemicist Richard West, who reported an incident at Oxford where the Vice Chancellor-a Tory highflyer named Roger Manderprohibited a student from reading "a copy of Verses upon the Inscription on the Medal, at Her Majesties Coronation, VICEM GERIT ILLA TONANTIS." According to West, "Some People were apt to think this an Affront upon the present Government; but I am so Charitable as to imagine he thought it only shew'd a Contempt of the Last," by which he means William's Whig ministry. ${ }^{78}$ We must be cautious in accepting West's story at face value; he divulges the episode in a polemical context designed to discredit Tory opponents such as Mander. West would not have been alone in inventing tall tales to score political points; as Daniel Defoe put it just over a year later, "Interest, Parties, Strife, Faction, and particular Malice, with all the scurvy Circumstances attending such things, may prompt Men to strain a Tale beyond its real Extent." 79 That said, in order to be polemically effective the story had to be credible. Thus we can be reasonably certain West is either relating something that actually happened, or, at the very least, was likely enough to have happened that his readers believed it anyway. For Man-

75. Essays Serious and Comical (London, 1707), 239.

76. On Anne's Tory succession panegyrics, see Hone, "Politicising Praise," $148-51$.

77. In The Conquest of Grenada (1672), Dryden calls the mob a "many-headed Beast": see Works, 11:111. I am grateful to James Anderson Winn for bringing this passage to my attention. The hydra images of Tory visual propaganda are very different to the giant on the coronation medal; compare "Faction Display'd," BM, item 1868,0808.3419.

78. [Richard West?], The True Character of a Church-Man, Shewing the False Pretence to That Name. Together With the Character of a Low Church-Man Drawn in Answer to It, With Remarks (London, 1702), 40.

79. Daniel Defoe, The Storm, ed. Richard Hamblyn (London, 2005), 64. 

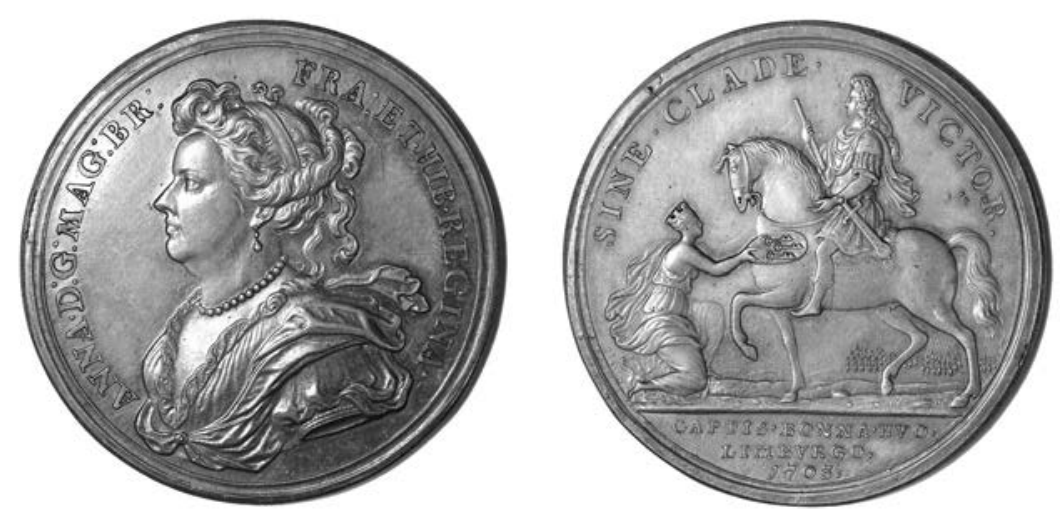

FIGURE 4. Isaac Newton and John Croker, medal for capture of Bonn, Huy, and Limburg (1704). (C) Trustees of the British Museum, G3,EM.245.

der and those who shared his political outlook, nothing could be so objectionable as the Whiggish sentiment that Anne's reign would simply pick up where the previous administration had left off. For Tories, Anne's accession was an opportunity for real political change, away from the Whig dominance of William's reign. They did not see this reflected in the coronation medal and therefore, if we are to believe West, attempted to impede the dissemination of its message.

Perhaps the most politically volatile medal of Anne's reign was produced in early 1704 to commemorate the previous summer's military campaign, in which Marlborough had captured the cities of Bonn, Huy, and Limburg with minimal loss of life (fig. 4). Hence the motto "SINE. CLADE. VICTOR.," meaning, "a conqueror without slaughter." Modeled on a French medal of 1694 made for the return of Louis XIV to Paris, the reverse shows a crowned female figure surrendering the keys to those cities to a solitary horseman, who is, according to the official notes on the design, emblematic of the allied army. But the public interpreted it very differently. Several pamphleteers, among them the radical hack John Tutchin and Jacobite conspirator Sackville Tufton, saw Marlborough himself on the reverse, in a position usually reserved for the monarch; recent practice dictated against the portrayal of subjects on official medals. Although Newton maintained in public that the medal was purely allegorical, he was probably shrewd enough to guess how the medal would be interpreted. Again, Newton's intention is impossible to determine. But the subtlety with which he had politicized the coronation medal is testament to his ability as a covert partisan. Aware of the strong likelihood that the horseman would be taken as the allied generalissimo, Newton probably exploited the ambiguity in the design to compliment Marlborough. ${ }^{80}$ 
By 1704, praise of Marlborough had become a quick and easy way of advertising Whig credentials. Although the general, like the queen, wished to remain above party conflict and hardly considered himself a Whig figurehead, Whig poets such as Thomas Tickell, Charles Gildon, and Joseph Addison apotheosized Marlborough in their panegyrics, while drinking songs and toasts in his favor became a staple at Whig political clubs. ${ }^{81}$ If Newton could not commission medals explicitly dedicated to the duke's person - which would have gone against protocol-he could manipulate the design of an official medal to pursue his own partisan ends. Maintaining in official documents that the horseman was emblematic gave Newton some level of deniability. If questioned by the authorities, he could plausibly argue that any political reading of the medal was a case of misinterpretation, not seditious design.

Unfortunately, Newton had not accounted for the duke's enemies, who quickly seized upon the medal as evidence he aspired to royal status. Having returned from war, Marlborough shall, as Tutchin put it, "Ride in Triumph over his Queen." ${ }^{2}$ And an anonymous libel circulating widely in manuscript pushed the point much further:

The glory of the English arms retriev'd

Shall scarce in after ages be believed.

For should they take the trusty medalls word

These conquests were not owing to the sword.

In good Queen Besse's days her generalls fought,

And not from bloodlesse fields their Lawrells brought.

Yet good Queen Besse herselfe would always side

And scorn'd to lett her subjects get astride.

Thus then the Treasurer inspir'd the Queen,

And taught her how to conquer and to reigne:

Nor durst attempt so daring a designe

To stamp his Queen and Cuckold on one coine. ${ }^{83}$

The central conceit is a contrast-rather than the more usual comparison-of the reigns of Anne and Elizabeth. ${ }^{84}$ Reflecting on the motto, the satirist suggests that the

81. See Williams, Whig Literary Culture, 138-50. On the vogue for poems on Marlborough, see Robert D. Horn, Marlborough: A Survey; Panegyrics, Satires, and Biographical Writings, 1688-1788 (New York, 1975).

82. The Observator 15 (May 13, 1704). For Tufton's alternative interpretation, see The History of Faction, Alias Hypocrisy, Alias Moderation, From Its First Rise Down to Its Present Toleration in These Kingdoms (London, 1705), 115-16.

83. I have taken as my copy text, MS. Smith 23, fol. 109r (cf. fol. 127r), Bodleian Library, Oxford; the verso has a complementary poem, "The Reverse. Clades Sine Victoria," describing Marlborough as a "Whiggish upstart." See also BL, Add. MSS 36663, fol. 522v; 4006o, fol. 50; 72479, fol. 85; 78522, fol. 42; Poetry Box IV/119, Beinecke Library, Yale University; MS. Eng. 6o6, fol. 45, Houghton Library, Harvard University.

84. On this comparison, see Vincent Carretta, "Anne and Elizabeth: The Poet as Historian in Windsor-Forest," Studies in English Literature, 1500-1900 21 (1981): 425-37; John Watkins, Representing Elizabeth in Stuart England (Cambridge, 2002), 206-19. 
"trusty" medal actually misrepresents the magnitude of recent military campaigns, which had proved no more "bloodlesse" than those waged under Elizabeth. His most pointed remark, though, is directed at Godolphin. By recalling how Elizabeth's Treasurer-William Cecil, Lord Burghley- "inspir'd the queen" with his policies, the poem directs a swipe at the current holder of the office, Godolphin. Indeed, the final reference to Marlborough as Godolphin's "Cuckold" alluded to the baseless rumor (widespread in scurrilous lampoons) that Godolphin was Sarah Churchill's lover. This attack on Anne's chief minister contains an implicit critique of the government itself. Little wonder the poem circulated only in manuscript. ${ }^{85}$ Certainly, Newton never anticipated that the medal would misfire so spectacularly as to implicate his friend and colleague.

The episode was no flash in the pan. On March 28, Sir William Simpson promised to send John Methuen, the English ambassador to Portugal, a set of "libels" upon the medal. His letter insinuates the whole affair was contrived by Godolphin, hinting that one of these lost libels may well have been the above poem. ${ }^{86}$ Evidently concerned for her husband's reputation, Sarah Churchill, Duchess of Marlborough, soon wrote to the Lord Treasurer seeking advice. Despite Godolphin's high stake in the situation, his reply betrayed disinterest. He was a man of old-fashioned tastes and set no store by the political valence of medals, for all his involvement in their production. ${ }^{87} \mathrm{He}$ was, of course, wrong to assume the brouhaha would simply blow over. The medal was still being discussed in polemical terms as late as $1712 .{ }^{88}$ As one anonymous journalist put it that year, "Who can forget the Time, when Sine clade Victor, was thought a proper Motto for a Returning General after a glorious Campaign?"89

The furor over this medal led to an important shift in strategy. After 1704 medal designs moved away from the emblems and symbols the public had previously misinterpreted and appropriated. Instead they depicted scenes of battle and victory that, as we have seen, demanded an unambiguous interpretation: the presiding female deities patently stood in for the queen. That shift was due largely to increased ministerial supervision of the process by which medals were designed, made, and distributed.

\section{$\sim$ Medals as Government Propaganda}

Unlike Godolphin, Robert Harley understood the potential propaganda value of modern medals. He was a lifelong medal enthusiast, collecting and cataloguing ancient

85. On the manuscript circulation of "clandestine satires," see Harold Love, Scribal Publication in Seventeenth-Century England (Oxford, 1993); Love, English Clandestine Satire, 1660-1702 (Oxford, 2004).

86. MSS C163, letter 29, Kenneth Spencer Research Library, University of Kansas.

87. Sidney, Lord Godolphin, to Sarah, Duchess of Marlborough, June 14, 1704, in The MarlboroughGodolphin Correspondence, ed. Henry Snyder, 3 vols. (Oxford, 1975), 1:322. See Peter Barber, "Marlborough and the Medal: A Proposed Blenheim Medal of 1704-5," Seaby Coin and Medal Bulletin 773 (1983): 2-9.

88. See Charles Hornby, The Fourth and Last Part of a Caveat Against the Whiggs (London, 1712), 76; No Queen or No General: An Argument Proving the Necessity Her Majesty Was In to Displace the Dof $M-$ ([Dublin], 1712), 9-10.

89. The Examiner 3 (November 13, 1712). 
specimens for his extraordinary library. His son, Edward, inherited this fascination; when he commissioned Michael Dahl to paint his portrait in 1728 , he sat with a medal from Anne's reign displayed in his open left hand (fig. 5). $9^{\circ}$ Thus when the 1704 medal backfired, Harley quickly moved to limit the damage. We know he had pre-publication access to Coningham's essay on the subject, which defended the medal from its detractors. He encouraged the writer and was at least partly responsible for the essay's publication, if only in ignoring Godolphin's request that it be suppressed, though he may have taken a more active role in this piece of ministry propaganda. ${ }^{91}$ Under Harley's direction, the ministry launched a sweeping inquiry into how the Mint allowed the problematic 1704 medal to be struck. Despite publicly defending the medal in question as pure allegory, Newton accepted that changes would need to be made. In August 1704 he recommended that "hereafter no medalls be made in ye mint without order from her Matie to ye Master \& Worker of ye mint." 92 Another proposal followed, clamping down on the production of royal effigies on unofficial medals. Moreover, it was decided the Mint could not "disperse any such medals before a specimen of them hath been showed" to the Lord Treasurer and, by extension, the queen.93 By the autumn of 1706 the procedures were put in place, and on November 2, Anne issued a warrant to formalize the changes. 94 As Peter Barber notes, the new regulations placed English medallists under similar controls to those prevailing at Louis's Académie, and were probably heavily influenced by the example of the French court.95 And according to these procedures, any ministerial intervention in medal design - whether official or covert-would have gone through Newton, not Croker.

There had been a hiatus in medal-making while the new regulations were being drawn up. That hiatus came to an end in December 1706, when, nearly two and a half years after the battle, the medal honoring Marlborough's victory at Blenheim was finally approved and produced. The medal commemorating Ramillies followed before the end of the year, and a further six medals appeared over the next twelve months. ${ }^{6}$ Two of those were reissues: the Palladium and the double-portrait medal,

90. The original portrait is held at Welbeck Abbey in Nottinghamshire. Perhaps this artistic nod to Anne was a subtle declaration of Edward Harley's ongoing sympathies for the Stuarts. In 1725 the Duke of Wharton included Harley in a list of Jacobite peers, and, on the accession of George II in 1727, Harley, together with the Jacobite controversialist William Shippen, boycotted the Hanoverian court. So the medal in the portrait may be a covert Jacobite symbol_covert because it recalled a legitimate Protestant Stuart monarch, but a Stuart nonetheless. On Edward Harley's political standing, see The History of Parliament: The House of Commons 1715-1754, ed. Romney Sedgwick, 2 vols. (New York, 1970), 2:110-11. Compare Henry Overton's 1731 medley print of Popeiana adorned with a medal of Queen Anne (of a style consistent with the ones produced in 1710) and the passage from WindsorForest ending “peace \& plenty tell a Stuart reigns': BM, item J,7.44 (emphasis in original print).

91. Godolphin to Duchess of Marlborough, June 14, 1704, in The Marlborough-Godolphin Correspondence, 1:322

92. TNA, Mint 19/1, fol. 94.

93. Ibid., fol. 83. See also fol. 147, printed in Correspondence, 7:435-36.

94. TNA, Mint 3/18.

95. Barber, "Commemoration and Control," 3.

96. BL, Add. MS 18757, fol. 5r. 


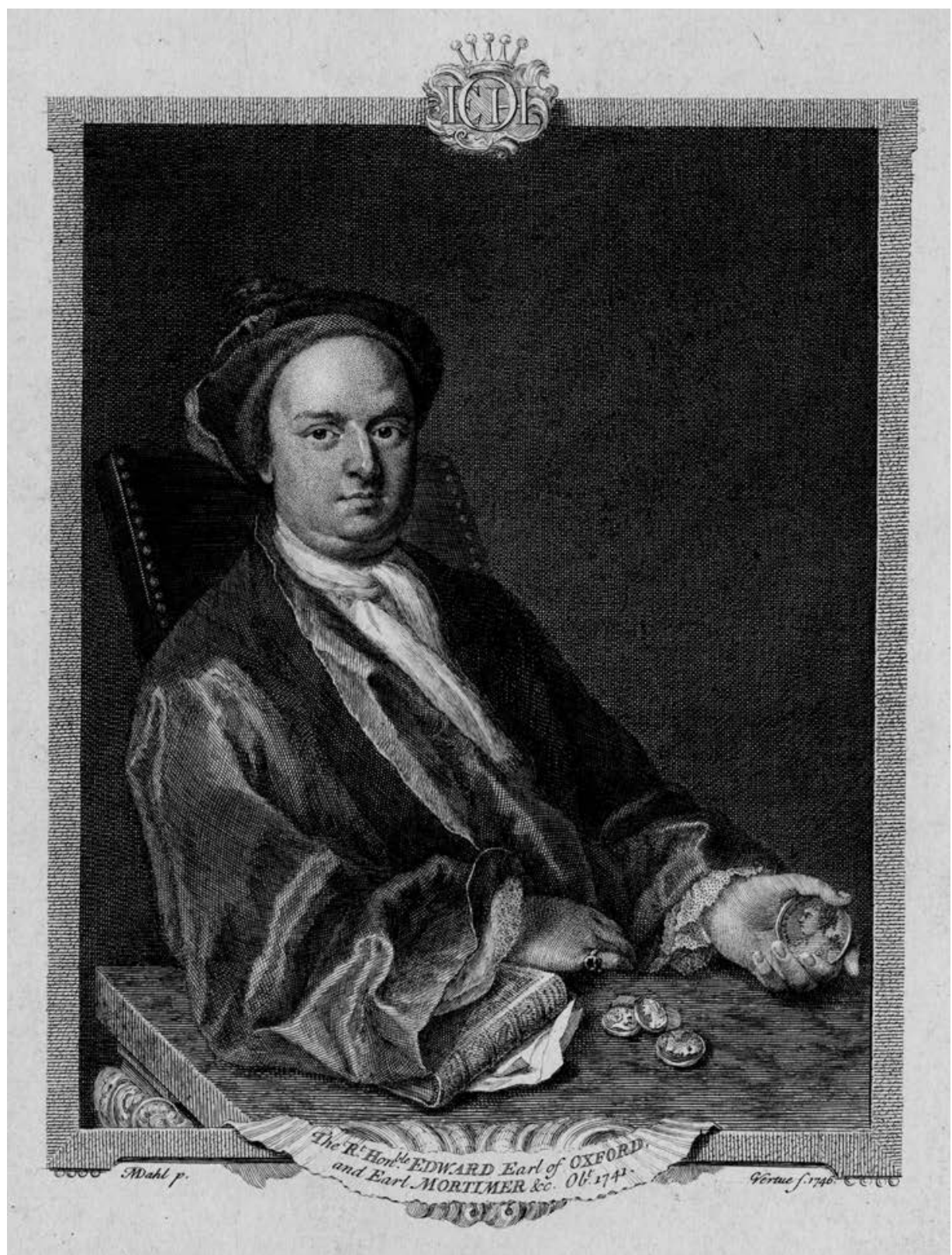

FIGURE 5. George Vertue after Michael Dahl, The Rt. Honble. Edward Earl of Oxford (1746). @ Trustees of the British Museum, 1849,1031.64. 
both originally released in the year of Anne's accession. A further two were minted for the Act of Union, and were released in different sizes; the small, token-sized medal was aimed at a less socially elite audience.

These medals were subject to significant ministerial interference at the approval stage. Newton insisted the inscription on the Blenheim medal be altered by inserting details of the numbers of men injured and killed in the battle and of captured standards: "Capt: et. Cæs: XXX:M. Sign: relat: CLXIII."97 The statistics were intended to reflect the magnitude of the victory. Pickup finds this intrusion "difficult to comprehend." 98 But Newton was clearly acting under orders. The ministry was eager to promote the battle as a watershed victory. Before the year was out, Godolphin had commissioned Joseph Addison, then an up-and-coming poet, to write his panegyric on the battle, The Campaign (1704). 99 Addison's reward was a salaried government post. Likewise, Harley released a hundred pounds from a secret-service slush fund to sponsor the young Tory encomiast, John Philips, to write a rival poem, Blenheim (1705). Philips's payment was signed off on by the queen herself. ${ }^{100}$ Harley also had Daniel Defoe, his trusted agent in the press, inflate the significance of the victory via his news organ, The Review, which reported the same statistics. ${ }^{101}$ The demands made of the severely delayed medal probably resulted from similar ministerial pressures.

Similarly, when signing off on the Union medal, Newton insisted it be dated, which had not been the original plan. Again, the order probably came from Harley. The final approved design was not the one originally submitted by Newton. He had earlier proposed a medal featuring "Her Maty in royal apparel in the posture of Britannia sitting on a globe with a speare in her right hand \& a shield standing by her, to represent both her self \& her mystical body Britannia. The sheild to be charged with the new Arms of great Britain. In her left hand a Rose and Thistle upon one stalk. The Rose towards her right hand. In the Prospect below, two rivers (Tamesis \& Boderia) unite into one common stream. Over her head two hands, to signify this union is the work of heaven, come out of the clouds holding a single Crown to crown her." ${ }^{102}$ Croker's preliminary sketches for the design survive in the Mint papers at the National Archives at Kew. ${ }^{103}$ The first thing to note is Newton's acknowledgement here of Britannia as Anne's "mystical body," supporting the argument that female deities on medals stand in for the queen. The second point of interest is the symbolic richness of the design compared to the final medal, which is a fairly straightforward presentation of the royal coats of arms.

97. Ibid., fol. 4V.

98. Pickup, "John Croker and the Alchorne Manuscript," 19.

99. See Robert D. Horn, “Addison’s Campaign and Macaulay," PMLA 63 (1948): 886-902.

100. TNA, MS T 48/17, fol. 3. See John D. Baird, "Whig and Tory Panegyrics: Addison's The Cam-

paign and Philips's Blenheim Reconsidered," Lumen: Selected Proceedings from the Canadian Society for Eighteenth-Century Studies 26 (1997): 163-77; Juan Christian Pellicer, "Harleian Georgic from Tonson's Press: The Publication of John Philips's Cyder, 29 January 1708," The Library 7 (2006): 185-98.

101. Daniel Defoe, A Review of the Affairs of France, ed. John McVeagh, 9 vols. (London, 2003-11), 1:307-9.

102. Correspondence, 4:509.

103. TNA, Mint 19/3, fol. 304r. 
It is impossible to say precisely why this design was scrapped: there are no clues in the paperwork. The surviving evidence suggests, however, that the finished medal may have been based on a design proposed from outside the Mint. We do not have any preliminary sketches in Croker's hand, as we do for almost every other design. Such arrangements were not unheard of. Newton had previously complained to Godolphin that alternative designs were being passed on to the government "by others." 104 In 1704 a German engraver had approached Marlborough directly with proposals for a medal commemorating Blenheim. ${ }^{105}$ And in February 1713, Harley received unsolicited designs for "historical medals" from "T. Sadler," a name that does not appear in Leonard Forrer's catalogue of medallists. ${ }^{106}$ Perhaps Harley thought the rich symbolism of Newton's proposal made less of a statement than the united English and Scottish coats of arms. Or perhaps Anne simply disliked the design, preferring instead a medal without her portrait on the reverse. Either way, Newton may have used this snub to justify the reissue of the Palladium medal from Anne's accession.

The New Year saw a new propaganda threat, in the form of Jacobite medals. Early in 1708, Norbert Roettier, medallist to the exiled Jacobite court, coined the first widespread medal promoting James Francis Edward's claim to the British throne. Roettier was responding to the surge of medals being produced by the Mint over the previous year, which had undoubtedly found their way across the Channel. The reverse of this Jacobite medal showed a map of the British Isles with the legend "REDITE," meaning, "render" or "give back." It was an obvious allusion to Christ's parable of the tribute, with its exhortation to render unto Caesar-that is, "James III"-what is rightfully his. Originally cast in silver and copper, and only the size of a small halfpenny, these medals were intended to accompany James Francis Edward in his attempted invasion of Scotland in the spring of 1708. ${ }^{107}$ Once the troops had landed, the medals were to have been freely distributed as a way of garnering popular support for James's cause. Unfortunately for the Jacobites, bad weather and the English fleet meant they never got the opportunity to land the army, let alone offload their cargo.

Although the invasion failed spectacularly, the medals-which were eventually smuggled across the Channel a year or so later-became a serious nuisance. In July 1710 the medal came to the attention of the London press and was subject to scathing commentary by Tutchin and others; Defoe wrote at least two pamphlets against it, although precisely which pamphlets remains unclear. ${ }^{108}$ Then, on June 30,1711 , the situation escalated when the Duchess of Gordon formally presented a specimen to the Faculty of Advocates in Edinburgh, who accepted the gift despite-or possibly because of-its political valence. ${ }^{109}$ The stunt was probably coordinated by her husband,

104. Correspondence, 4:429.

105. Barber, "Marlborough and the Medal," passim.

106. Wiltshire, Longleat House, Portland Papers, 9:199. See Leonard Forrer, Biographical Dictionary of Medallists, 8 vols. (London, 1902-30).

107. On the potential significance of the invasion, see Daniel Szechi, Britain's Lost Revolution? Jacobite Scotland and French Grand Strategy, 1701-8 (Manchester, 2014).

108. Daily Courant 2726 (July 19, 1710); The Observator 54 (July 22, 1710); The Letters of Daniel

Defoe, ed. George Harris Healey (Oxford, 1955), 350.

109. See Guthrie, The Material Culture of the Jacobites, 23-25. 
George, Duke of Gordon, who had earlier been arrested for his involvement in the failed Jacobite invasion. This was a public relations disaster for the Faculty, who became the target of a flood of polemical tracts and satires during the summer of 1711. ${ }^{110}$ Correspondence between Harley and his deputy Henry St. John, Viscount Bolingbroke, reveals their concern about the circulation of Jacobite medals in the wake of the scandal. ${ }^{111}$ This is demonstrated once again by Bolingbroke's swift legal action on September 28, 1711, when he signed a warrant for the pirate printer Henry Hills and his associates "for publishing and vending a scandalous and seditious Libel" called $A$ Welcome to the Medal, which the minister suspected was authored by the High Church controversialist and rabid Jacobite William Pittis. ${ }^{112}$ It seems likely the twelve new medals produced shortly after Harley's successful bid for power in 1710 reflect the new first minister's priorities in countering the potential threat of Jacobite propaganda. Medals were part of the ideological defense system he set in place. But Harley was not always so high-minded in his encouragement of medal-making. Responding to the Sacheverell affair of 1710, and to the wave of High Church populism that followed, he recommissioned the medal for Queen Anne's Bounty in a bid to remind the public of the ministry's Anglican credentials. ${ }^{113}$ Official medals could, it seems, also be used opportunistically to boost one's political standing.

The final medals of Anne's reign, produced in 1713 to mark the end of Britain's involvement in the War of the Spanish Succession, were also among the most important. Over the preceding few years, peace negotiations had tested the Grand Alliance toits breaking point; but a peace treaty was eventually settled and signed by French and British representatives in the small Dutch town of Utrecht. Severing the Grand Alliance proved a highly contentious decision. Although Britain gained much by the treaty-including a monopoly over the lucrative Asiento slave trade-many Whigs were reluctant to exit the war with anything less than France's unconditional surren-

110. The Scotch Loyalty: or, An Account of the Scotch Lady's Present to the Scotch Advocates (London, 1711); Scotch-Loyalty Exemplify'd, in the Behaviour of the Dean of the Faculty and His Brethren at Edinburgh in Relation to the Reception of a Medal of the Pretender (London, 1711); The Scotch Medal Decipher'd, and the New Hereditary-Right Men Display'd (London, 1711); Loyalty Display'd: or, An Answer to the Factious and Rebellious Song, Call'd Welcome to the Medal (London, 1711); A Welcome to the Medal: or, An Excellent New Song Call'd, The Constitution Restor'd (Oxford [i.e., London], 1711); John Spotiswood, The Truth at Last: or, The Whole Affair of the Scotch Medal (London, 1711).

111. Nottingham, University of Nottingham Library, MS Pw2 Hy 1368.

112. Copies Taken from the Records of the Court of King's Bench, at Westminster of Warrants Issued by Secretaries of State (London, 1763), 16; Calendar of Treasury Books: Preserved in the Public Records Office, ed. William Shaw, 32 vols. (London, 1907-57), 26:cdix; TNA, SP 44/77, fols. 127-28. On the whole episode, see Niall MacKenzie, "Double-Edged Writing in the Eighteenth Century," in Literary Milieux: Essays in Text and Context, ed. David Womersley and Richard McCabe (Newark, Del., 2008), 140-68. On Pittis in particular, see Theodore F. M. Newton, "William Pittis and Queen Anne Journalism," Modern Philology 33 (1936): 169-86 and 279-302; John McTague, “"There is No Such Man as Isaac Bickerstaff': Partridge, Pittis, and Jonathan Swift," Eighteenth-Century Life 35 (2011): 83-101.

113. On the Sacheverell Crisis, see Brian Cowan, The State Trial of Doctor Henry Sacheverell, Parliamentary History 6 (Oxford, 2012); Geoffrey Holmes, The Trial of Doctor Sacheverell (London, 1973); Faction Displayed: Reconsidering the Impeachment of Dr Henry Sacheverell, ed. Mark Knights, Parliamentary History 31, pt. 1 (Chichester, 2012). 
der. Harley had been instrumental in countering these opinions by commissioning propaganda for the peace, particularly via his two principal literary agents, Jonathan Swift and Daniel Defoe, although he also employed lesser writers, such as Abel Boyer. ${ }^{114}$ Their job was to persuade the public that they were best served by peace, and any opinion to the contrary was nothing less than warmongering.

It seems likely Harley was also responsible for the tightly coordinated release of two sets of medals on the occasion. The medals were of similar design. As convention demanded, the obverse had a royal portrait, surrounded by official titles. Meanwhile, the reverse gave a vista of bucolic peace and plenty on land and sea, not dissimilar to the georgic vision of Pope's poem on the peace, Windsor-Forest (1713). ${ }^{115}$ At the center of this scene, in the guise of Britannia, is the queen. A large version of the medal, valued at twenty pounds in gold, featured Britannia enthroned. The smaller of the two medals was produced by royal command and showed Britannia standing with an olive branch in her hand. The first design was approved on March 11,1713, anticipating the signing of the treaty by over a fortnight. ${ }^{116}$ The second followed shortly after, the ministry having clearly recognized the need for visual material supporting the contentious treaty. At Harley's encouragement, Anne issued a warrant for the production of 812 of these smaller gold medals, to be distributed among Members of Parliament, visiting diplomats, courtiers, and other members of the political elite. The total cost to the Treasury

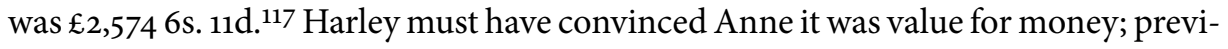
ously, only coronation medals had been funded by the state. The gesture was, in part, an attempt to buy the silence of those politicians and foreign ministers who had decried the peace settlement in its preliminary stages. But it also put forward a new vision for the reign. Anne's earlier medals had all deployed, in one way or another, a martial iconography, presenting her as a warrior queen, not a herald of peace. The government was now facing a very different set of political circumstances. So were the medallists. After all, medals were usually struck to commemorate military victories. Once the production of this final medal was underway, Newton and his colleagues must have wondered how the Mint could continue to make medals in an era of peace.

Harley had been considering the future direction of numismatic propaganda since the beginning of the peace preliminaries. Following his rise to power, Harley had made frequent use of medals as a vehicle of propaganda, putting Newton and Croker to work as often as he did Defoe. Harley set the task to one of his most trusted aides,

114. On Harley's role in facilitating peace propaganda, see J. A. Downie, Robert Harley and the Press: Propaganda and Public Opinion in the Age of Swift and Defoe (Cambridge, 1979), 131-48; Arne Bialuschewski, "A True Account of the Design, and Advantages of the South-Sea Trade: Profits, Propaganda, and the Peace Preliminaries of 1711," Huntington Library Quarterly 73 (2010): 273-85.

115. See Pat Rogers, The Symbolic Design of Windsor-Forest: Iconography, Pageant, and Prophecy in Pope's Early Work (Newark, Del., 2004)"; Rogers, Pope and the Destiny of the Stuarts: History, Politics, and Mythology in the Age of Queen Anne (Oxford, 2005); Joseph Hone, "Pope and the Politics of Panegyric," Review of English Studies 66 (2015): 106-23.

116. BL, Add. MS 18757, fol. 14r. Sketches for potential alternative designs for the Utrecht medal are on fol. 35r. They include a design showing Pallas handing over her thunderbolts to a phoenix, with the Thames and London in the background. This recalled the coronation medal design.

117. Calendar of Treasury Books, 27:360. 
Jonathan Swift. Having resigned the editorship of The Examiner in 1712, Swift was now an adviser on matters of propaganda. And, like Harley, he was an enthusiastic numismatist. In various tracts, including Some Remarks on the Barrier Treaty (1712), Swift constructed polemical arguments with reference to medals. ${ }^{118}$ Perhaps most famously, in Verses on the Death of Dr. Swift (1731) he made a show of complaining that Princess Caroline never sent him the medals she had promised as payment for a shipment of Irish linen. ${ }^{119}$ Among Swift's treasured possessions when he died were the doubleportrait medal of Anne and Prince George and the medal for Queen Anne's Bounty, probably from the reissue of 1711 , when he was at the pinnacle of his political career. ${ }^{120}$ He was, then, an appropriate choice for considering the future direction of Anne's medallic image.

On January 22, 1713, just a few months before the peace was ratified, Swift presented his solution. In the Journal to Stella, he recalls Harley had "fallen in with my Project (as he calls it) of coining Halfpence \& Farthings, with devices like Medals, in honor of te Q, evry year changing te Device." ${ }^{121}$ Six months later-just as the Utrecht medals were being circulated-the details of the project were relayed to the public in Joseph Addison's paper The Guardian. While noting that "nothing can so much contribute as Medals" to "perpetuate the Glories of Her Majesty's Reign," Swift acknowledges they are "not Numerous enough to spread among the People." He thus suggests, first, that all farthings and halfpence should be recoined with "Devices and Inscriptions alluding to all the most remarkable Parts of her Majesty's Reign"; second, that "there be a Society established for the finding out of proper Subjects, Inscriptions, and Devices"; and third, that "no Subject, Inscription, or Device be stamped without the Approbation of this Society, nor, if it be thought proper, without the Authority of Privy-Council." 122

Necessary to the commerce of everyday life, coins will prove a more effective vessel for ministry propaganda than medals, Swift argues. Moreover, whereas medals were struck relatively infrequently, in response to events, a steady flow of new coins needed to be put into circulation each year. If owning medals had been the preserve of the elite, Swift was now proposing a popular mode of numismatic propaganda. His intention was not to preserve Anne's image for posterity; the existing medals already did that. Rather he hoped to influence public opinion here and now. For Swift, copper coins "are of undoubted Authority, of necessary Use and Observation, not perishable by Time, nor

118. Cambridge Edition of the Works of Jonathan Swift, 8:135.

119. See Howard Erskine-Hill, "'Verses on the Death of Dr. Swift': The Interest of Cuts and Gaps," in Swift's Travels: Eighteenth-Century British Satire and Its Legacy, ed. Nicholas Hudson and Aaron Santesso (Cambridge, 2008), 143-59 at 150-51. On Swift's medal collecting, see Memoirs of Laetitia Pilkington, ed. A. C. Elias, 2 vols. (Athens, Ga., 1997), 1:394.

120. The Prose Writings of Jonathan Swift, ed. Herbert Davis et al., 16 vols. (Oxford, 1939-74), 13:156. 121. Cambridge Edition of the Works of Jonathan Swift, 9:486.

122. Joseph Addison and Richard Steele, The Guardian, ed. John Calhoun Stephens (Lexington, Ky., 1982), 344-45. It is possible that the passage quoted, though originally by Swift, has been tampered with by Addison. 
confined to any certain Place; Properties," he continues, "not to be found in Books, Statues, Pictures, Buildings, or any other Monuments of Illustrious Actions." 123 They are, in short, the perfect mode of propaganda, preferable even to government sponsored "Books," by which he probably had in mind newspapers like The Examiner. As such, medals needed to be tightly regulated by a "Society" of experts such as Swift himself.

The project was obviously close to Swift's heart: "I wish it may be done," he wrote to Stella. ${ }^{124}$ But circumstances were against him. It is easy to see why Swift's project never got off the ground. Its scope was massive and did not take into account the important technical aspects of coinage design, which are not a problem with medals. And, besides, the queen was not long for this world. The succession crisis precipitated by her turn for the worse kept the ministry in limbo: Harley was trying to secure the best possible outcome, maintaining public support for the Hanoverian succession while writing behind the scenes to James Francis Edward, urging him to change his religion. Bolingbroke had split from his former master and was now intriguing even more deeply with the Jacobites. There was no time for an administrative overhaul in the midst of such political machinations. When Anne finally succumbed to her illnesses on August 1, 1714, Harley was swiftly ejected from office and impeached for his part in making the Peace of Utrecht. In one fell swoop, two of the country's chief proponents of medals were gone. When the time came for designing King George's coronation medal, the new ministers did not contact Newton until just a few weeks before the finished product was needed, seemingly unaware of the procedures that had been fine-tuned over the previous decade. Never again would medals achieve the same level of influence in Britain.

The evidence of the interference to which medal designs were subjected after 1704 demonstrates that the authorities were fully alive to their propaganda value. Like the periodicals and polemical tracts of Swift and Defoe, medals were produced as part of a coordinated campaign, designed to bolster the ministry policies through images of the queen. That Harley turned to Swift for advice on the future direction of state numismatics is telling. Clearly he realized that coins and medals demanded the same attention to detail as literary modes of propaganda. With this in mind, following the reforms of 1704, Harley made Newton his agent in the Mint. He was, to be sure, no political hack. But neither was he an aloof scholar, innocent of contemporary politics. Besides his willingness to embrace ministerial intervention and intricate knowledge of mythography and symbolism, it was probably his understanding of - and ongoing participation in-party politics that recommended Newton to Harley as the ideal candidate for coordinating government propaganda on medals.

contributor's note overleaf

123. Addison and Steele, The Guardian, 345.

124. Cambridge Edition of the Works of Jonathan Swift, 9:486. 
$\sim 148$ JOSEPH HONE

D JOSEPH HONE is a retained lecturer in English literature at Jesus College, Oxford. He has published articles in Review of English Studies, Philological Quarterly, Journal for Eighteenth-Century Studies, and elsewhere. He is writing a book about Alexander Pope. 